\title{
Revision of Piezochaerus (Coleoptera: Cerambycidae)
}

\author{
Jose R. M. Mermudes
}

Departamento de Zoologia, Universidade do Estado do Rio de Janeiro. Rua São Francisco Xavier 524, Maracanã, sala 516, 20550-013 Rio de Janeiro, Rio de Janeiro, Brasil.E-mail: jrmermudes@uol.com.br

\begin{abstract}
Piezochaerus and the species P. bondari Melzer, 1932 (type-species) are redescribed. Three new species are described from Brazil: P. monnei sp. nov. (Linhares, Espírito Santo) have dorsal pubescence whitish gray with a bluish reflection depending on the direction of illumination; basal half of the epipleuron with a spot formed by orangish pubescence; P. melzeri sp. nov. (Pedra Azul, Minas Gerais and Pedro Canário, Espírito Santo) with elytra narrower at the apex, sides converging towards the apex beginning at the basal 1/3; apex without external spine; elytral pubescence yellowish with brownish spot, developed and oblique at the base and other median; and P. marcelae sp. nov. (Juiz de Fora, Minas Gerais) with unicolor dorsal pubescence, whitish gray, elytra not depressed; bicolorous femurs, witch is orangish in the basal $2 / 3$, dark in the apical $1 / 3$. An illustrated key to the species is also included.
\end{abstract}

KEY WORDS. Acanthocinini; Lamiinae; Neotropical; systematics.

RESUMO. Revisão de Piezochaerus (Coleoptera: Cerambycidae). Piezochaerus Melzer, 1932 é revisto, com a redescrição do gênero e de $P$. bondari Melzer, 1932 (espécie-tipo). Três espécies novas do Brasil são descritas: $P$. monnei sp. nov. (Linhares, Espírito Santo) com pubescência dorsal cinza-esbranquiçada e com reflexo azulado dependente da direção da incidência de luz; metade basal da epipleura com mancha formada por pubescência alaranjada; $P$. melzeri sp. nov. (Pedra Azul, Minas Gerais e Pedro Canário, Espírito Santo) élitros mais estreitos para o ápice, lados convergentes para o ápice desde o 1/3 basal; ápice sem espinho externo; pubescência elitral amarelada com mancha castanho, desenvolvida e oblíqua na base e outra mediana; e P. marcelae sp. nov. (Juiz de Fora, Minas Gerais) com pubescência dorsal unicolor, cinza-esbranquiçada; élitros não deprimidos; fêmures bicolores, alaranjados nos dois terços basais, escuros no terço apical. Chave e ilustrações de todas as espécies são incluídas neste estudo. PALAVRAS-CHAVE. Acanthocinini; Lamiinae; Neotropical; sistemática.

Piezochaerus was proposed by Melzer (1932) for P. bondari Melzer, 1932, from Bahia, Brasil. Later it was merely listed by ZIKÁN \& WYgodZINSKY (1948). Recently, MonNÉ (2005) kept this genus in the tribe Acanthocinini, that today comprises 149 genera and 950 species in the neotropical region. Here, we redescribe the genus and the type-species, with an identification key and description of three new species.

The material is deposited at the Museu Nacional, Universidade Federal do Rio de Janeiro, Rio de Janeiro (MNRJ) and the Museu de Zoologia, Universidade de São Paulo, São Paulo (MZSP). Measurements are in millimeters.

\section{Piezochaerus Melzer, 1932}

Piezochaerus Melzer, 1932: 428; Zikán \& Wygodzinsky, 1948: 63; Monné, 2005: 121.

Type-species: P. bondari Melzer, 1932: 429 (monotypy and original designation). From Brazil, Bahia (São Salvador), deposited at the MZSP.
Body slightly convex, suboval and somewhat elongated. Antennae with long and suberect bristles. Head subvertical, transverse and slightly convex frons. Vertex with slight sulcus, depressed between the tubercles, except in $P$. bondari. Eyes coarsely faceted, strongly emarginate. Gena short, about a third of the inferior ocular lobe. Labrum transverse and convex. Mandibles on the external face, with triangular area strongly depressed. Antennae filiform and elongated, longer than the elytral apex by the antennomere V or VI. Scape slightly thicker and elongated, reaching the base of the prothorax. Antennomeres III-VI thin.

Prothorax wider than long, slightly convex; next to the posterior margin, punctation in well-defined transverse row. Base of the prothorax thinner; sides diverging from anterior margin to the lateral and antebasal spines, which are strongly acuminate at the apex. Prosternum strongly transverse and narrow, length less than half that of the anterior coxal cavity. Narrow prosternal process, less than one fifth of the anterior

Revista Brasileira de Zoologia 25 (2): 309-313, June, 2008 
coxal cavity, which is rounded, slightly angular at the sides, closed posteriorly. Mesosternum impressed; narrow mesosternal process, less than one third of the median coxal cavity, which is closed on the sides. Scutellum as wide as long, amply rounded at the apical margin. Elytra elongated, slightly depressed at the base, except $P$. marcelae sp. nov., convergent towards the apex in the apical third. Humerus rounded and projected. Punctuation not very sharp. Apex emarginate with apical exteranal spine, more developed in P. monnei sp. nov.. Urosternite I slightly longer than II; II and IV subequal, and strongly transverse; $\mathrm{V}$ elongated and with convergent sides, apex truncated in $P$. marcelae sp. nov.; slightly emarginate in $P$. bondari; strongly emarginate with acute lateral projections in $P$. monnei sp. nov. Piezochaerus marcelae sp. nov., with urosternite II longer than III and IV, which are subequal.

Protarsomeres I as short as II or III. Mesotibiae sulcated on the apical third. Femur and tibia progressively elongated; profemur more robust; mesofemur subclavate and metafemur more linear.

Discussion. Melzer (1932: 429) considered Piezochaerus similar to the genera Anisopodus White, 1855 and Ozineus Bates, 1863. Piezochaerus differs from Anisopodus by the shorter posterior femur and the bristles on the elytra, and differs from Ozineus by the lack of basal carena and presence of bristles on the elytra. It shares bristles on the elytra with the genera Eutrichillus Bates, 1885 and Tithonus Thomson, $1864=$ Leptocometes Bates, 1881. Piezochaerus differs from Eutrichillus by the absence of basal carena on the elytra and from Tithonus by the shape of the lateral spines of the prothorax.

\section{Key to identification of the species of Piezochaerus}

1. Dorsal pubescence whitish gray with a bluish reflection depending on the direction of illumination; basal half of the epipleuron with a spot formed by orangish pubescence; mesosternal processo subequal to one third of the mesocoxa, emarginate at the apex (Fig. 3). Brazil (Espírito Santo).....

P. monnei sp. nov.

1 '. White, gray or yellowish pubescence, variegated or not, with blackish- brow spots, without bluish reflection; epipleuron without spot on the basal half; narrow mesosternal process, less than a third of the mesocoxa, subtruncated at the apex

2. Unicolor dorsal pubescence, whitish gray, elytra not depressed; bicolorous femurs, orangish in the basal $2 / 3$, dark in the apical 1/3 (Fig. 2). Brazil (Minas Gerais) P. marcelae sp. nov.

2 '. Bicolor dorsal pubescence, yellowish gray or white with blackish-brown spots; elytra depresssed at the basal half; unicolor femurs, brownish 3

3. Body clearly longer and narrow (four times longer than the humeral width). Elytra narrower at the apex, sides converging towards the apex beginning at the basal 1/3; apex without external spine; elytral pubescence yellowish with brownish spot, developed and oblique at the base and other median; several small spots, blackish-brown and somewhat rounded. Females with urotergite VII and urosternite $\mathrm{V}$ elongated and narrow, approximately three times longer than IV (Fig. 4). Brazil (Minas Gerais and Espírito Santo) P. melzeri sp. nov.

3'. Oblong-oval body, (2.6x longer than the humeral width). Elytra slightly narrowed in the apical third; sides converging after the middle; apex with external spine; elytral pubescence whitish or whitish-gray, with irregular brownish spot at the apical half of the epipleuron, barely reaching the dorsal area (if with blackish-brown spots, small spots) Females with urotergite VII and urosternite V a bit longer than wide (Fig. 1) P. bondari

\section{Piezochaerus bondari Melzer, 1932 Fig. 1}

Piezochaerus bondari Melzer, 1932: 429, pl. 6, fig. 6; Zikán \& Wygodzinsky, 1948: 63; Monné, 2005: 122.

Integument brownish, dark to reddish; legs slightly darker on the internal part of the femora and apical half of the tibiae and tarsi. Whitish gray or whitish yellow dorsal pubescence, somewhat dense on the sides of the pronotum and elytra. Pronotum either blackish-brown spots or not. Elytra with a irregular, post-median spot, oblique on the epipleuron reaching to the dorsal region of the apical half; sometimes with small dark spots. Elytra with long, suberect bristles. Sides of the prosternum, meso- and metepisternum blackish-brown. Antennae with few, short bristles. Eyes, on posterior margin, with dense, yellowish white pubescence. Trapezoidal vertex slightly depressed between the tubercles.

Antennae exceeding elytral apices, at least by half antennomere VI. Scape slightly longer than III; III-VII decreasing in length.

Prosternum either slightly depressed at the front of the procoxae or not. Elytra depressed, wider at the base, and more strongly depressed near the humerus to the antemedian region. Sides converge beginning at the middle of the elytra; elytral apex with spiniform projection on the external side.

Last tergite of the male, with apical margin slightly projecting in the middle; last urosternite subtruncated at the apex. Tarsi of males wider and pubescent.

Females with abdominal tergites and sternites somewhat longer than wide; tergite weakly more truncated and urosternite emarginate.

Type material. Holotype male, deposited at MZSP, not examined. Photgraph of the studied holotype is available in "A Photographic Catalog of the Cerambycidae of the New World" avalable at http://plant.cdfa.ca.gov/byciddb/ default_wImage.asp.

Examined material. BrazIL, Mato Grosso: Vera $\left(12^{\circ} 46^{\prime}\right.$ S,

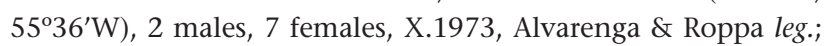

Revista Brasileira de Zoologia 25 (2): 309-313, June, 2008 

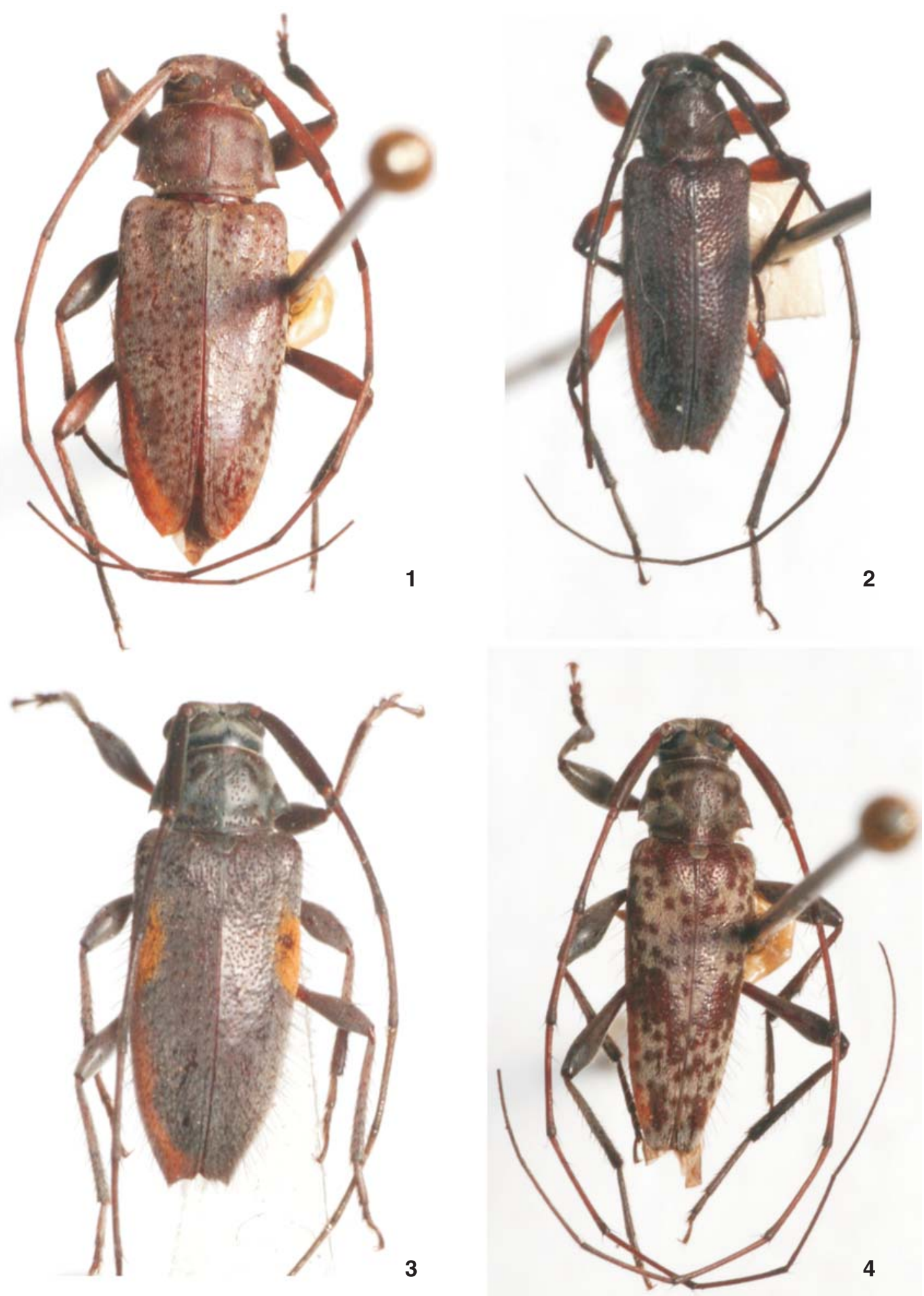

Figures 1-4. 1, Piezochaerus bondari, Sinop, Mato Grosso, length $8 \mathrm{~mm}$; (2) P. marcelae sp. nov., Juiz de Fora, Minas Gerais, length 6 mm; (3) P. monnei sp. nov., Linhares, Espírito Santo, length 6 mm; (4) P. melzeri sp. nov., Pedra Azul, Minas Gerais, length, 7 mm. 
Sinop ( $\left.12^{\circ} 31^{\prime} \mathrm{S}, 55^{\circ} 37^{\prime} \mathrm{W}\right)$, BR $163, \mathrm{~km} 500$ to $600,350 \mathrm{~m}, 1$ male, 1 female, X.1974, Alvarenga \& Roppa leg.; Minas Gerais: Pedra Azul (700 m), 1 male, 1 female, XI.1970, Seabra \& Oliveira leg.; Espírito Santo: Linhares, 1 male, X.1971, B. Silva leg.; Pedro Canário, 1 male, 1 female, X.1972, Oliveira \& Roppa leg., 1 M, XI.1972, B. Silva leg.; Rio de Janeiro: Rio de Janeiro (Guanabara, Rep. Rio Grande), 1 male, X.1960, F.M. Oliveira leg.; São Paulo: Marilia, 1 male, XI.1945, H. Zellibor leg. (MNRJ). Argentina: 1 female, excol. Bosq. Provincia de Rioja 2 F; Tucuman, 1 female; Formosa, 1 F, ex-col. Bosq. (MNRJ).

Total length. Males 8-11, females 8-13.

Discussion. Piezochaerus bondari is most similar to P. melzeri sp. nov. due to the dorsal pattern on the elytra. It is distinguished by, in addition to characters in the key, small dark chestnut spots and by the oblique, post-median spot on the epipleurum that reaches the dorsal region at the apical half. The elytra of $P$. melzeri sp. nov. have rounded and larger dark chestnut spots and two irregular bands, one median and the other subapical.

Here we extend the geographic distribution of $P$. bondari, to include Brazil, in the states of Bahia, Mato Grosso, Minas Gerais, Espírito Santo, Rio de Janeiro and São Paulo.

\section{Piezochaerus marcelae sp. nov.}

\section{Fig. 2}

Etymology. In homage to Marcela L. Monné, researcher at MNRJ, for her knowledge of the Neotropical Cerambycidae.

Integument blackish-brown; bicolorous femurs: basal 2/ 3 orangish; apical $1 / 3$ and rest of legs and antennae, lightbrown. Covered dorsally with dense shiny and whitish gray pubescence. Elytra with suberect, blackish-brown bristles. Femurs and antennae, from the scape to antennomere VIII, sparsely bristled. Tibia with slightly more bristles on the basal half; apical half of the tibias also with shorter, strongly dense black bristles.

Antennae elongated, with apex of antennomere V exceeding the elytra; scape somewhat shorter than III, subequal with IV; IV-XI decreasing in length.

Pronotum slightly convex, moderately coarsely and densely punctate; microsculptured interstices; more stongly depressed near the posterior margin, punctate, moderately coarse, in two irregular rows. Prosternum narrow, shorter than $1 / 2$ the procoxa. Mesosternal process short, sharp, rounded at the apex.

Elytra slightly convex, clearly narrower, punctation moderately coarse and dense; slightly depressed base around disc. Elytral apex slightly emarginate. Urosternite V truncated at the apex, without latero-apical projection.

Type material. Holotype male. BraziL, Minas Gerais: Juiz de Fora, XII.1981, G.S. Andrade leg. (MNRJ).

Total length. Male 6.

Discussion. Piezochaerus marcelae sp. nov. differs from other species by the following: unicolor dorsal pubescence, whitish gray, without dark spots; elytra not depressed; bicolored femurs, orangish on the basal $2 / 3$, dark on the apical $1 / 3$.

\section{Piezochaerus monnei sp. nov.}

\section{Fig. 3}

Etymology. In homage to Miguel A. Monné, researcher at MNRJ, for his incentives in the study of Neotropical Lamiinae.

Male. Integument blackish-brown. Dorsl pubescence grayish white, dense and with a bluish reflection depending upon the angle of light. Basal half of the elytra with orangish pubescent spot, brilliant and dense, covers part of the epipleuron and sides of the elytral disc. Dorsum of the elytra, femurs and tibiae with blackish-brown, suberect bristles. Ventral surface of body with whitish, dense pubescence. Antennae with blackish-brown bristles, moderately long and sparse from the scape to antennomere VII.

Antennae elongate, passing the elytral apex mid antennomere VI. Scape subequal to length of III; IV-V slightly decreasing in length; VI-X subequal and slightly shorter than V; XI 1/ 3 shorter than $\mathrm{X}$.

Pronotum, on the disc, moderately coarsely and densely punctate. Posterior margin moderately coarsely punctate in two irregular rows. Prosternum uniformely convex. Mesosternal process emarginate at the apex. Elytra slightly more convex at the apical half; with accentuated basal depression near the humerus and around the disc. Elytral apex emarginate due to the developed and triangular projection on the external side (Fig. 3).

Urosternite $\mathrm{V}$, strongly emarginate at apex, with fine, lateral projections.

Tarsomere I slightly shorter than tarsomera II-V together.

Type material. Holotype male, BrazIL, Espiríto Santo: Linhares, Dec. 69 [on the back of the label], without collector (MNRJ). Paratype male; (Sooretama Park), 17-27.X.1962, F.S. Pereira leg. (MNRJ).

Total length, males: 6-7.

Discussion. Piezochaerus monnei sp. nov. differs from other species by: whitish gray dorsal pubescence with bluish reflection depending on light incidence; basal half of the epipleuron with developed spot with orangish pubescence; mestosternal process width subequal to $1 / 3$ mesocoxa, apex emarginate; tarsomere I slightly shorter than the sum of tarsomera II-V.

\section{Piezochaerus melzeri sp. nov.}

Fig. 4

Etymology. In homage, posthumously, to J. Melzer, for starting the study of Neotropical Cerambycidae.

Blackish-brown integument; light-brown antennomera with slightly darker apex. Dense, gray pubescence covers the entire head, except the antennal tubercles which have blackish-brown pubescence; pronotum with medial narrow band that does not reach the anterior margin; both sides of the pronotum and prothorax with irregular, emarginate, spot; elytra with yellowish pubescence with blackish-brown spots, the most developed of which are medial and basal; diverse additional blackish-brown and rounded spots. Ventral surface and legs with 
pubescence similar in color to the dorsum, but thin and denser

Elongated antennae exceeding the elytral apex at the base of antennomere VI; scape as long as III; IV subequal to III; VVIII slightly decreasing; IX 1/3 longer than VIII; X 1/3 longer than IX; XI almost twice as long as X.

Pronotum impressed at the disc, moderately coarsely punctate, denser towards the longitudinal band; one or two transverse rows, coarsely punctate. Prosternum not punctate, length slightly greater than half procoxa; prosternal process narrow, with elevated lateral margins. Emarginate mesosternal process apex.

Elytra clearly thinner, with convergent sides to apex from base. Elytral base amply elevated, with moderately coarse and evident punctation. Discrete elytral apex, obliquely truncate, without spines or projections. Urosternite V slightly angulated in the middle, shallow apical sulcus.

Female. Urotergite VII and urosternite V narrow and elon- gate, approximately three times longer than IV, truncated at apex. Type material. Holotype male, Brazil. Minas Gerais: Pedra Azul (700 m), XI.1972, Seabra \& Oliveira leg. (MNRJ). Paratypes: 1 male, same information as holotype; 1 female, Espírito Santo: Pedro Canário (C. da Barra), XI.1972, B. Silva leg. (MNRJ).

Total length. Male 7-11, female 7.

Discussion. See discussion for $P$. bondari.

\section{LITERATURE CITED}

Melzer, J. 1932. Novos gêneros e novas espécies de cerambicídeos do Brasil. Revista de Entomologia 2 (4): 420-434.

Monné, M.A. 2005. Catalogue of the Cerambycidae (Coleoptera) of the Neotropical Region. Part II. Subfamily Lamiinae. Zootaxa 1023: 1-759.

Zikán, W. \& P. WygodZinsky.1948. Catálogo dos tipos de insetos do Instituto de Ecologia e Experimentação Agrícolas. Boletim do Serviço de Pesquisas Agronômicas 4: 1-93.

Submitted: 23.I.2008; Accepted: 15.V.2008.

Editorial responsibility: Márcia Souto Couri 